\title{
The Right to an Ecologically Balanced Environment in Brazil
}

\author{
Luciane Martins De Araújo* \\ Department of Environmental Science, Brazil
}

*Corresponding author: Luciane Martins De Araújo, Department of Environmental Science, Master's degree in Agrarian Law, Lawyer at Rede Gaia Environmental Advisors, Brazil

Submission: 眥 March 06, 2018; Published: 眥 March 12, 2018

\section{Opinion}

The 1988 Constitution still represents a great achievement to democracy and fundamental rights in Brazil, even if it has almost 30 years old. Known as the "Citizen's Constitution", it was a pioneer in affirming the fundamental right to an ecologically balanced environment when it comes to the constitutional history of Brazil. This right is connected to the quality of life, the obligation to defend and preserve the environment being a task both for the Public Administration and the collectivity, moulding their behavior in the sake of present and future generations and in the context of sustainable development. Since the 1981 National Environmental Policy Act and after the 1988 Constitution, various environmental norms were enacted, aiming at the effectiveness of this right. As examples, there are the federal acts concerning water resources, solid waste management, public sanitation, climate change, conservation units, and environmental crimes, among others. Even if these norms are a clear evidence of the importance held by environmental protection, one cannot ignore that they also represent a threat for economic interests, such as the agribusiness, that has powerful representatives in the National Congress.

As a consequence, after a long period of conflicts among environmentalists, scientists and politicians linked to the powerful Brazilian agribusiness, the 1965 Forest Code was revoked in 2012, by the lawn. 12,651- the new Forest Act.

What we can see by the new rules is that Brazil has lost in terms of environmental protection. There was a great setback for key institutes that once protected the native vegetation, such as the permanent preservation areas and the legal reserve. The first ones consist on a legal obligation to preserve fragile areas, like water courses or mountain tops; the latter is a legal obligation to preserve native vegetation that exists only In Brazil, for rural landowners In this way, for properties located in biotopes like Mata Atlântica and Cerrado $20 \%$ of native vegetation must be kept, in the Amazon Rainforest region the percentage is of $80 \%$ of the land. Both institutes had great setbacks with the new forest Act, especially from what the law defines as "rural consolidated areas" - the areas already occupied by farming before July $22^{\text {nd }}, 2008$ and where rural activities may go on, whether they are originally preservation areas or not. Landowners are not be held responsible for the deforestation of these areas, if it was made before the above mentioned date. This legal amnesty holds the account for the great increase on deforestation in the country in the last years and is a clear violation of the Environmental Law's Non Regression Principle. This violation of the fundamental right to the environment lead this norm to have its constitutionality judged before the Brazilian Supreme Court (STF). After more than 5 years, in February 2018, the verdict was announced and, for everyone's surprise, this Constitutional Court recognized the constitutionality of various dispositions of the law, a fact that concerns even the rural consolidated areas, as well as the amnesty for landowners that made illegal deforestation before July 2008

As a consequence, native vegetation in permanent preservation and in legal reserve areas that was illegally suppressed before 2008 won't be completely restored, due to the new legal demands: in rural consolidated areas only a minor part of the vegetation is to be recovered. As an illustration, a brief comparison with the revoked forest code shows that the areas that must be restored have reduced from 50 to 21 million hectares in Brazilian territory. If we take the Cerrado, the second Brazilian largest biome, as an example, this law represents not only biodiversity loss but also a huge threat for water resources. This is because it is considered a "water cradle", as its vegetation promotes the storage of rainwater in the subsoil. In this way, the recognition of the constitutionality of the 2012 Forest Act is clearly a setback concerning the right to an ecologically balanced environment as well as a violation of the non regression principle. In this judgment, Brazilian Supreme Court simply didn't take into consideration the elements arising from the global development agenda-the Sustainable Development Objectives-, nor global problems such as climate change, an attitude that will bring damage for present and future generations. 

(c) (i) Creative Commons Attribution 4.0

For possible submissions Click Here

Submit Article

\section{EAES \\ Environmental Analysis \& Ecology Studies}

\section{Benefits of Publishing with us}

- High-level peer review and editorial services

- Freely accessible online immediately upon publication

- Authors retain the copyright to their work

- Licensing it under a Creative Commons license

- Visibility through different online platforms 